\title{
Pediatric Acute Liver Failure in Sickle Cell Disease
}

\author{
Luís Rodrigues $^{\mathrm{a}, \mathrm{b}}$ Sofia Almeida ${ }^{\mathrm{a}}$ Catarina Salgado ${ }^{c}$ Cristina Gonçalves $^{\mathrm{d}}$ \\ a Pediatric Intensive Care Unit, Department of Pediatrics, Hospital de Santa Maria, Centro Hospitalar Universitário \\ Lisboa Norte, Lisbon, Portugal; ' ${ }^{b}$ Department of Pediatrics, Hospital do Espírito Santo de Évora, Évora, Portugal; \\ ${ }^{c}$ Hematology Unit, Department of Pediatrics, Hospital de Santa Maria, Centro Hospitalar Universitário Lisboa Norte, \\ Lisbon, Portugal; ${ }^{d}$ Gastroenterology Unit, Department of Pediatrics, Hospital de Santa Maria, Centro Hospitalar \\ Universitário Lisboa Norte, Lisbon, Portugal
}

\section{Keywords}

Acute liver failure - Exchange transfusion · Intrahepatic cholestasis $\cdot$ Pediatrics $\cdot$ Sickle cell disease

\section{Abstract}

Introduction: Sickle cell intrahepatic cholestasis (SCIC) is one of the rarest and the most severe acute hepatic manifestations of sickle cell disease (SCD) and it can rapidly progress to acute liver failure. It is associated with a high mortality rate, demanding prompt recognition and management. Case Presentation: We report a case of a 7-year-old boy with a history of homozygous HbS SCD who presented to the emergency department with fever, increasing abdominal pain, and jaundice. His course was complicated by acute liver injury (AST 9,472 IU/L, ALT 2,683 IU/L, total bilirubin 15.4 $\mathrm{mg} / \mathrm{dL}$; conjugated bilirubin $8.69 \mathrm{mg} / \mathrm{dL}$, hypoalbuminemia $2.6 \mathrm{~g} / \mathrm{dL}$, and persistent hypoglycemia), with acute liver failure (coagulopathy not corrected by vitamin $\mathrm{Kadministration}$ with INR 3.26, decreased factors V $10 \%$ and VII $28 \%$, and West Haven grade I hepatic encephalopathy associated with mild hyperammonemia of $71 \mu \mathrm{mol} / \mathrm{L}$ ). After excluding other causes of acute liver failure, the patient was diagnosed as having SCIC and was successfully treated with manual exchange transfusion. Conclusion: This case reinforces that ex- change transfusion is an effective treatment for SCIC and that it should be introduced promptly to prevent fulminant and potentially fatal liver failure.

(c) 2021 Sociedade Portuguesa de Gastrenterologia Published by S. Karger AG, Basel

\section{Falência Hepática Aguda em Idade Pediátrica na Doença de Células Falciformes}

\section{Palavras Chave}

Falência hepática aguda · Exsanguineotransfusão . Colestase intrahepática · Pediatria · Doença de células falciformes

\section{Resumo}

Introdução: A colestase intra-hepática falciforme (CIHF) é uma das manifestações hepáticas agudas mais raras e graves da doença de células falciformes (DCF), que pode progredir rapidamente para falência hepática aguda. Associa-se a uma elevada taxa de mortalidade, que exige identificação e intervenção imediatas. Caso clínico: Descreve-se o caso de um rapaz de 7 anos com DCF, homozigótico para a HbS, que recorreu ao serviço de urgên- karger@karger.com www.karger.com/pjg

Karger $\stackrel{\text { ' }}{5}$

BOPEN ACCESS (c) 2021 Sociedade Portuguesa de Gastrenterologia Published by S. Karger AG, Basel

This is an Open Access article licensed under the Creative Commons Attribution-NonCommercial-4.0 International License (CC BY-NC) (http://www.karger.com/Services/OpenAccessLicense), applicable to the online version of the article only. Usage and distribution for commercial purposes requires written permission.
Correspondence to:

Luís Rodrigues, luisnorterodrigues@gmail.com 
cia por febre, dor abdominal de agravamento progressivo e icterícia. Verificou-se evolução para lesão hepática aguda (AST 9,472 UI/L, ALT 2,683 UI/L, bilirrubina total 15.4 $\mathrm{mg} / \mathrm{dL}$; bilirrubina conjugada $8.69 \mathrm{mg} / \mathrm{dL}$, hipoalbuminemia $2.6 \mathrm{~g} / \mathrm{dL}$, hipoglicemia persistente), com falência hepática aguda (coagulopatia não corrigida por administração de vitamina $\mathrm{K}$ com INR 3.26, diminuição dos fatores V $10 \%$ e VII $28 \%$, assim como encefalopatia grau I (critérios de West Haven) e hiperamoniemia ligeira $71 \mu \mathrm{mol} / \mathrm{L}$ ). Após exclusão de outras etiologias de falência hepática aguda, o doente foi diagnosticado com CIHF e realizada exsanguineo-transfusão manual, com sucesso. Discussão/Conclusão: Este caso reforça que a exsanguineotransfusão é uma terapêutica eficaz na CIHF, que deve ser instituída precocemente para prevenir falência hepática fulminante e potencialmente fatal.

(C) 2021 Sociedade Portuguesa de Gastrenterologia Publicado por S. Karger AG, Basel

\section{Introduction}

Sickle cell disease (SCD) is a common hemoglobinopathy that can affect multiple organ systems, including the gastrointestinal tract [1]. The hepatobiliary system is one of the most common intra-abdominal organs involved in SCD, with hepatic involvement in $10-40 \%$ of sickle cell crises. Manifestations range from mild hyperbilirrubinemia to acute liver failure, and it is a rare condition that represents one of the most challenging of all critical pediatric illnesses [2].

\section{Case Presentation}

A 7-year-old African boy with a history of homozygous $\mathrm{HbS}$ SCD presented to the emergency department with a 24-h history of fever, increasing abdominal pain and vomiting, chest pain, and dry cough. His SCD was previously complicated by recurrent pain crises requiring hospitalization and cholelithiasis, although there were no clinical, biochemical, or imaging features of chronic liver disease prior to this event. His medication included hydroxyurea $500 \mathrm{mg}$ and folic acid $5 \mathrm{mg}$ daily. He had no other comorbidities.

On physical examination, the patient was drowsy (grade I hepatic encephalopathy according to West Haven criteria), ill-appearing, pale, and dehydrated. He was afebrile, with an adequate blood pressure of $114 / 55 \mathrm{~mm} \mathrm{Hg}$, a pulse rate of 120 beats/min, a capillary refill time of $4 \mathrm{~s}$, a respiratory rate of 30 breaths $/ \mathrm{min}$, and oxygen saturation of $94 \%$ on room air. Breath sounds were clear to auscultation bilaterally. Heart sounds were normal with no audible murmurs and a regular rate and rhythm. There was right-upperquadrant tenderness and the liver edge was palpable $2 \mathrm{~cm}$ below the right costal margin. The spleen was nonpalpable. The remaining systemic examination was normal.

Initial laboratory evaluation demonstrated hemoglobin $5.6 \mathrm{~g} /$ dL (baseline hemoglobin 8-8,5 g/dL), leukocytes 9,500/ $\mu \mathrm{L}-$ neutrophils $7,200 / \mu \mathrm{L}(75.3 \%)$, platelets $131,000 / \mu \mathrm{L}$, serum glucose 27 $\mathrm{mg} / \mathrm{dL}$, creatinine $1.0 \mathrm{mg} / \mathrm{dL}$, blood urea $49.5 \mathrm{mg} / \mathrm{dL}$, sodium 138 $\mathrm{mmol} / \mathrm{L}$, potassium $4.9 \mathrm{mmol} / \mathrm{L}$, aspartate aminotransferase (AST) $200 \mathrm{IU} / \mathrm{L}$, alanine aminotransferase (ALT) $48 \mathrm{IU} / \mathrm{L}$, total bilirubin $11.8 \mathrm{mg} / \mathrm{dL}$, direct bilirubin $2.8 \mathrm{mg} / \mathrm{dL}$, lactate dehydrogenase (LDH) $1,249 \mathrm{IU} / \mathrm{L}$, and C-reactive protein $18.95 \mathrm{mg} / \mathrm{dL}$. Blood gas analysis showed metabolic acidosis, with a venous $\mathrm{pH}$ of 7.01 , venous partial pressure of carbon dioxide $32.1 \mathrm{~mm} \mathrm{Hg}$, venous bicarbonate $8.1 \mathrm{mmol} / \mathrm{L}$, base excess $-22.7 \mathrm{mmol} / \mathrm{L}$, and venous lactate $16 \mathrm{mmol} / \mathrm{L}$. There was no pulmonary opacity on the chest X-ray.

Initially, he received fluid resuscitation with normal saline bolus $(10 \mathrm{~mL} / \mathrm{kg})$ and then red blood cell transfusion $(5 \mathrm{~mL} / \mathrm{kg})$. The hypoglycemia was corrected with dextrose $10 \%$ bolus and ceftriaxone was empirically started. However, his clinical picture progressively worsened, with indicators of respiratory distress like tachypnea, retractions of the muscles of the chest wall, and grunting, so he was transferred to the Pediatric Intensive Care Unit (PICU) for further management.

On the first day of admission in PICU, he became progressively more lethargic and had increasing abdominal pain and jaundice but remained hemodynamically stable (MAP $>75 \mathrm{~mm} \mathrm{Hg}$ ) with spontaneous breathing, without a need for organ support. His blood analysis showed a significant worsening: AST 9,472 IU/L, ALT 2,683 IU/L, lactate dehydrogenase 10,621 IU/L, total bilirubin $15.4 \mathrm{mg} / \mathrm{dL}$ (from which $>50 \%$ was conjugated bilirubin $-8.69 \mathrm{mg} /$ $\mathrm{dL}$ ), associated with coagulopathy (international normalized ratio [INR] 5.16 and partial thromboplastin time 94.8/29 s) not corrected by vitamin K administration (INR 3.26), and persistent hypoglycemia despite a high glucose infusion rate (maximum $10 \mathrm{~g} /$ $\mathrm{kg} /$ day). Ammonia ranged from 71 to $63 \mu \mathrm{mol} / \mathrm{L}(\mathrm{N}:<60)$. Other values showing diminished hepatic synthesis included low factor V (10\%, N: 50-100), factor VII (28\%, N: 70-130), fibrinogen (67 $\mathrm{mg} / \mathrm{dL})$ and albumin $(2.6 \mathrm{~g} / \mathrm{dL})$, with normal factor VIII $(94 \%, N$ : $50-150)$. He continued to have kidney injury with a creatinine of $0.68 \mathrm{mg} / \mathrm{dL}$ (baseline creatinine $0.22-0.31 \mathrm{mg} / \mathrm{dL}$ ), and blood urea $57 \mathrm{mg} / \mathrm{dL}$. Peripheral blood smear showed anisopoikilocytosis, hypochromia, multiple sickle cells, and Howell-Jolly bodies.

The etiological investigation was negative and included toxicology screening (in the urine and paracetamol serum level); serologic screening for viral hepatitis (i.e., HAV, HBV, HCV, and HEV), Epstein-Barr virus, Cytomegalovirus, Coxsackievirus, Echovirus, Parvovirus, and Herpes simplex virus types 1 and 2; antinuclear-, smooth-muscle, and liver-kidney-microsomal antibodies; ceruloplasmin; and alpha-1 antitrypsin. Abdominal ultrasound revealed hepatomegaly and cholelithiasis, but there was no evidence of intra- or extrahepatic biliary duct obstruction or dilation and there were no signs of chronic liver disease. The liver vascular ultrasound showed patent hepatic vasculature and appropriate blood flow. Ceftriaxone was changed to cefotaxime due to cholestasis.

The case was discussed by the multidisciplinary team (PICU, Hematology, and Hepatology), the diagnosis of SCIC was considered, and exchange transfusion was decided. For this purpose, a central catheter was placed in the patient's right jugular vein. Exchange transfusion was performed using repeated alternating isovolumetric phlebotomy and blood transfusion, with a subsequent $\mathrm{HbS}$ of $13.2 \%$. 
Table 1. Acute hepatobiliary manifestations of sickle cell disease

\begin{tabular}{lllll}
\hline $\begin{array}{l}\text { Acute } \\
\text { manifestations of } \\
\text { SCD }\end{array}$ & Clinical presentation & $\begin{array}{l}\text { Amino-transferases } \\
\text { (AST, ALT) }\end{array}$ & ALP & Bilirubin \\
\hline $\begin{array}{l}\text { Sickle cell hepatic } \\
\text { crisis }\end{array}$ & $\begin{array}{l}\text { Fever, abdominal pain, jaundice } \\
\text { and tender hepatomegaly }\end{array}$ & $\begin{array}{l}\text { Elevated up to 3 } \\
\text { fold the upper limit } \\
\text { of normal }\end{array}$ & $\begin{array}{l}\text { Normal to slightly } \\
\text { elevated }\end{array}$ & $\begin{array}{l}\text { Elevated up to } \\
15 \text { mg/dL, } \\
\text { mainly conjugated }\end{array}$ \\
\hline $\begin{array}{l}\text { Hepatic } \\
\text { sequestration }\end{array}$ & $\begin{array}{l}\text { Sudden severe RUQ pain, } \\
\text { hepatomegaly and rapidly } \\
\text { worsening anemia }\end{array}$ & Normal & $\begin{array}{l}\text { Elevated up to } \\
\text { transfusion }\end{array}$ & $\begin{array}{l}\text { Elevated up to } \\
\text { 24 mg/dL, } \\
\text { mainly conjugated }\end{array}$ \\
\hline $\begin{array}{l}\text { Sickle cell } \\
\text { intrahepatic } \\
\text { cholestasis }\end{array}$ & $\begin{array}{l}\text { Fever, RUQ pain, acute } \\
\text { liver failure and multi-system } \\
\text { organ failure }\end{array}$ & $\begin{array}{l}\text { Elevated; typically } \\
>1,000\end{array}$ & $\begin{array}{l}\text { Normal or elevated } \\
\text { up to 1,000 U/L }\end{array}$ & $\begin{array}{l}\text { Elevated up to } \\
>30 \text { mg/dL, } \\
\text { mainly conjugated }\end{array}$ \\
\hline
\end{tabular}

SCD, sickle cell disease; AST, aspartate aminotransferase; ALT, alanine aminotransferase; ALP, alkaline phosphatase; RUQ, right upper quadrant.

Over the ensuing days, there was a quick favorable evolution of his clinical and laboratory status. The patient was discharged from the PICU to the Hematology ward 4 days after the exchange transfusion. His blood analysis showed a significant improvement: hemoglobin $9.5 \mathrm{~g} / \mathrm{dL}$, AST $178 \mathrm{IU} / \mathrm{L}$, ALT $377 \mathrm{IU} / \mathrm{L}$, total bilirubin $7.24 \mathrm{mg} / \mathrm{dL}$, INR 1.33, partial thromboplastin time 37.8/29 s, creatinine $0.39 \mathrm{mg} / \mathrm{dL}$, and blood urea $25 \mathrm{mg} / \mathrm{dL}$. Blood culture was positive for Streptococcuspneumoniae and cefotaxime was changed to ampicillin. The rest of his course was unremarkable.

\section{Discussion}

Sickle cell hepatopathy is an inclusive term encompassing the different kinds of liver disease found in patients with SCD [3]. The incidence of sickle hepatopathy is difficult to establish because abnormalities in liver function tests are common in these patients [4]. A spectrum of clinical manifestations may be observed for the same underlying pathophysiology, i.e., sinusoidal obstruction by sickled red blood cells resulting in hepatocyte ischemia, with secondary ballooning of adjacent hepatocytes and intracanalicular cholestasis. Depending on the relative degrees of ischemia, cholestasis, and cell trapping, the crisis may present as an acute sickle cell hepatic crisis, hepatic sequestration, or SCIC [5]. Classification can be difficult due to the overlapping diagnostic criteria (Table 1) $[2,6,7]$.

SCIC is one of the rarest and the most severe acute hepatic manifestations of SCD and a mortality rate of approximately $40 \%$ [6]. It presents initially as a severe acute hepatic crisis with fever, leukocytosis, right-upper-quadrant abdominal pain, and jaundice, but can rapidly prog- ress to multiple organ dysfunction including acute liver failure and acute kidney injury, as was seen in our patient [8]. Biochemical evidence showed significantly elevated bilirubin levels, which were mainly due to a rise in conjugated component; acute liver injury with transaminase levels $>1,000 \mathrm{mg} / \mathrm{dL}$, reflecting severe ischemic injury; and derangement of coagulation profile in the form of elevated prothrombin time, INR, and partial thromboplastin time $[2,6,7]$. SCIC is most commonly described in its acute form, but it can present as recurrent episodes, become chronic, and eventually evolve to progressive liver failure. To date, only 7 cases of chronic SCIC have been described in adults, and this entity is not well characterized [9]. To the best of our knowledge, there is no data on the incidence of recurrent or chronic SCIC in the pediatric setting.

An extensive workup for acute liver injury was undertaken and competing etiologies were excluded (viral infectious diseases, autoimmune diseases, Wilson disease, and alpha-1 antitrypsin deficiency). Sepsis-associated liver dysfunction (with later identification of S. pneumoniae) was also considered. During sepsis, not only infection itself, but also hyperactivity of the inflammatory response and microcirculatory failure are responsible for liver injury. Sepsis is almost invariably associated with coagulation abnormalities ranging from subclinical activation of blood coagulation to acute disseminated intravascular coagulation. The main cause of coagulopathy in sepsis is microvascular endothelial injury, resulting in an imbalance between fibrinolysis and coagulation, that leads to the consumption and subsequent depletion of platelets and coagulation factors (including factor VIII, which was nor- 
mal in our patient). Also, in pediatric septic shock, defined as severe infection leading to cardiovascular dysfunction (including hypotension, the need for treatment with a vasoactive medication, or impaired perfusion) [10], hypoxemia/liver hypoperfusion could explain hypoxic hepatitis and hyperbilirubinemia, as energy shortage during this process would impair most bile synthesis steps [11]. However, our patient was always hemodynamically stable, and there were no signs of decreased hepatic blood flow that would support this hypothesis. Finally, there was a significant improvement after the exchange transfusion treatment that reversed the acute liver injury, which would support the diagnosis of SCIC. Complications due to biliary disease such as cholecystitis and choledocholithiasis were excluded on abdominal ultrasound [12]. Although liver biopsy is virtually diagnostic of SCIC, it has been associated with serious complications when performed in patients with acute sickle cell hepatopathy, so the riskbenefit ratio must be considered. In our case, it was not performed in the setting of severe coagulopathy $[13,14]$.

As in this case, SCIC can rapidly progress to acute liver failure, defined as biochemical evidence of liver injury in a child without evidence of chronic liver disease, coagulopathy not corrected by vitamin $\mathrm{K}$ administration, and INR $>1.5$ if the patient has encephalopathy or $>2.0$ if encephalopathy is absent. This a life-threatening condition due to the unpredictable and potentially devastating complications as well as multiple organ system involvement. Proper management is dependent on intensive collaborative clinical care and implementing a timely and appropriate therapy $[15,16]$.

In patients with SCIC, therapy is aimed at aggressive supportive measures, including exchange transfusion to maintain a low level of $\mathrm{HbS}(<30 \%)[17,18]$. If supportive measures fail, patients are likely to have a worse prognosis, and liver transplantation remains the only viable therapeutic option. However, experience of liver transplantation for hepatic complications of SCD is limited; only 23 cases have been reported in the literature, with a survival rate of $66 \%$ in pediatric patients [6] and an increased risk of a vaso-occlusive crisis $[19,20]$. In this patient, we performed a manual exchange transfusion, which reversed the acute liver failure and avoided the need for a liver transplant. This is a time-consuming procedure, that needs skilled staff and constant medical supervision, and should only be performed in specialized units. Temporary renal replacement may be required for acute kidney injury, whose causes include acute tubular necrosis, hypovolemia, sepsis, nephrotoxic medications, and functional renal failure. We believe that, in this case, the acute kidney injury was the result of circulatory changes secondary to liver failure as it rapidly improved with the correction of the hepatic dysfunction $[21,22]$.

In summary, when a patient with SCD presents with abdominal pain and extreme hyperbilirubinemia, a careful and prompt evaluation is necessary to establish a diagnosis of sickle cell hepatopathy. Physical examination, laboratory workup, and appropriate diagnostic imaging are needed to diagnose and characterize sickle cell hepatopathy and exclude other conditions. This case shows one of the rarest and most extreme acute hepatic manifestations of SCD and reinforces that exchange transfusion is an effective treatment for SCIC. With the exchange transfusion, we were able to reverse the acute liver failure and change the outcome of a potentially fatal condition.

\section{Statement of Ethics}

Written informed consent was obtained from the patient for publication of the details of their medical case and any accompanying images.

\section{Conflict of Interest Statement}

The authors have no conflicts of interest to disclose.

Funding Sources

There was no funding.

\section{Author Contributions}

L.R. made the bibliographic research and wrote the manuscript with input from all authors. S.A., C.S., and C.G. provided critical feedback and contributed to the writing of the manuscript. All authors approved the manuscript prior to final submission.

References

1 Piel FB, Steinberg MH, Rees DC. Sickle Cell Disease. N Engl J Med. 2017 Apr;376(16) 1561-73.

2 Shah R, Taborda C, Chawla S. Acute and chronic hepatobiliary manifestations of sickle cell disease: a review. World J Gastrointest Pathophysiol. 2017 Aug;8(3):108-16.

3 Theocharidou E, Suddle AR. The Liver in Sickle Cell Disease. Clin Liver Dis. 2019 May; 23(2):177-89. 
4 Ebert EC, Nagar M, Hagspiel KD. Gastrointestinal and hepatic complications of sickle cell disease. Clin Gastroenterol Hepatol. 2010 Jun;8(6):483-9.

5 Allali S, de Montalembert M, Brousse V, Heilbronner C, Taylor M, Brice J, et al. Hepatobiliary Complications in Children with Sickle Cell Disease: A Retrospective Review of Medical Records from 616 Patients. J Clin Med. 2019 Sep;8(9):1481.

6 Alkhayyat M, Saleh MA, Zmaili M, Sanghi V, Singh T, Rouphael C, et al. Successful liver transplantation for acute sickle cell intrahepatic cholestasis: a case report and review of the literature. World J Hepatol. 2020 Mar; 12(3):108-15.

7 Pecker LH, Patel N, Creary S, Darbari A, Meier ER, Darbari DS, et al. Diverse manifestations of acute sickle cell hepatopathy in pediatric patients with sickle cell disease: a case series. Pediatr Blood Cancer. 2018 Aug; 65(8):e27060.

8 Ahn H, Li CS, Wang W. Sickle cell hepatopathy: clinical presentation, treatment, and outcome in pediatric and adult patients. Pediatr Blood Cancer. 2005 Aug;45(2):184-90.

9 Adkins BD, Savani BN, Booth GS. Management of Sickle Cell Intrahepatic Cholestasis: An Argument in Favor of Automated Exchange Transfusion. Clin Hematol Int. 2019 Sep;1(3):127-33.
10 Weiss SL, Peters MJ, Alhazzani W, Agus MS, Flori HR, Inwald DP, et al. Surviving sepsis campaign international guidelines for the management of septic shock and sepsis-associated organ dysfunction in children. Intensive Care Med. 2020 Feb;46(Suppl 1):10-67.

11 Woźnica EA, Inglot M, Woźnica RK, Łysenko L. Liver dysfunction in sepsis. Adv Clin Exp Med. 2018 Apr;27(4):547-51.

12 Simon E, Long B, Koyfman A. Emergency Medicine Management of Sickle Cell Disease Complications: An Evidence-Based Update. J Emerg Med. 2016 Oct;51(4):370-81.

13 Papafragkakis $\mathrm{H}$, Ona MA, Changela $\mathrm{K}$, Sadanandan S, Jelin A, Anand S, et al. Acute liver function decompensation in a patient with sickle cell disease managed with exchange transfusion and endoscopic retrograde cholangiography. Therap Adv Gastroenterol. 2014 Sep;7(5):217-23.

14 Zakaria N, Knisely A, Portmann B, MieliVergani G, Wendon J, Arya R, et al. Acute sickle cell hepatopathy represents a potential contraindication for percutaneous liver biopsy. Blood. 2003 Jan;101(1):101-3.
15 Lutfi R, Abulebda K, Nitu ME, Molleston JP, Bozic MA, Subbarao G. Intensive Care Management of Pediatric Acute Liver Failure. J Pediatr Gastroenterol Nutr. 2017 May;64(5): 660-70.

16 Squires JE, McKiernan P, Squires RH. Acute Liver Failure: An Update. Clin Liver Dis. 2018 Nov;22(4):773-805.

17 Howard J. Sickle cell disease: when and how to transfuse. Hematology (Am Soc Hematol Educ Program). 2016 Dec;2016(1):625-31.

18 Khalifeh H, Chamoun C, Elhoujairy A, Alkoussa W, Lahoud C, Masri G. Acute Hepatic Crisis in Sickle Cell Anemia: Favorable Outcome after Exchange Transfusion. J Hematol (Brossard). 2016;5(4):138-41.

19 Hurtova M, Bachir D, Lee K, Calderaro J, Decaens T, Kluger MD, et al. Transplantation for liver failure in patients with sickle cell disease: challenging but feasible. Liver Transpl. 2011 Apr;17(4):381-92.

20 Mekeel KL, Langham MR Jr, Gonzalez-Peralta R, Fujita S, Hemming AW. Liver transplantation in children with sickle-cell disease. Liver Transpl. 2007 Apr;13(4):505-8.

21 Malik A, Merchant C, Rao M, Fiore RP. Rare but Lethal Hepatopathy-Sickle Cell Intrahepatic Cholestasis and Management Strategies. Am J Case Rep. 2015 Nov; 16:840-3.

22 Khan MA, Kerner JA. Reversal of hepatic and renal failure from sickle cell intrahepatic cholestasis. Dig Dis Sci. 2011 Jun;56(6):1634-6. 